\title{
A Systematic Review of Corpus-Based Studies on Academic Writing in the Turkish Context ${ }^{*}$
}

\section{Türkiye Bağlamında Akademik Yazım üzerine Derlem-Temelli Çalışmaların Sistematik Değerlendirmesi}

\author{
Fatma YUVAYAPAN ${ }^{* *}$
}

\author{
Ceyhun YÜKSELİR*
}

Received: 13 December 2019

Review Article

Accepted: 19 June 2020

\begin{abstract}
Academic writing is rested on a view of academic negotiation between writers and readers in which writers ultimately aim to gain credibility in their academic discipline. In doing so, they utilize a wide range of linguistic devices based on cultural and disciplinary norms to communicate with readers and convince the readers about the truth of their claims. Based on a review of corpus-based studies about linguistic devices in academic writing conducted by Turkish scholars in the field of English Language Teaching and Linguistics, the present systematic review aims to show a general understanding of these devices in the lens of Turkish scholars in these fields. The systematic review has been carried out by postgraduate dissertations, MA theses and research articles in the past decade. Based on the results, it is found that Turkish academic writers had a different style of taking stance in their L1 and they mostly attempt to follow the linguistic conventions of both global and cultural communities in their discipline while writing academic genres in English.
\end{abstract}

Keywords: Systematic review, corpus-based studies, academic writing, Turkish context.

ÖZ: Bu çalışmada akademik yazım, yazarların akademik alanlarında inanılırlık kazanmayı amaçladıkları, yazarlar ve okuyucular arasındaki akademik uzlaşmaya dayanmaktadır. Bunu yaparken, okuyucularla iletişim kurmada ve okuyuculara iddialarının gerçekliklerini ikna etmede kültürel ve disiplinler arası normlara dayanan bir dizi dilbilimsel araçlardan faydalanmaktadırlar. Bu çalışmada, İngiliz Dili Eğitimi ve İngiliz Dilbilimi alanlarındaki Türk araştırmacılar tarafından yürütülen akademik yazım ile ilgili kültürlerarası derlem çalışmalarının incelemesi yapılmaktadır ve bu dilbilimsel araçların bu alanlardaki Türk akademisyenler tarafından nasıl algılandıklarının ortaya çıkarılması amaçlanmaktadır. Bunlar son on yıl içinde yapılan doktora ve yüksek lisans tezleri ve araştırma makaleleridir. Sonuçlara dayalı olarak, Türk akademik yazarların kendi anadillerinde farklı bir yazım şekli olduğu ve çoğunlukla İngilizce olarak akademik türde yazdıklarında hem küresel hem de kültürel grupların dilbilimsel kurallarını takip etme girişimleri olduğu bulunmuştur.

Anahtar kelimeler: Sistematik inceleme, derlem çalışmaları, akademik yazım, Türkiye bağlamı.

\footnotetext{
* This review study was presented as an oral presentation at $1^{\text {st }}$ International Language and Literature Congress, November 6-8, 2019. This is the final version of the study.

Corresponding Author: Asst. Prof. Dr., Kahramanmaraş İstiklal University, Kahramanmaraş, Turkey, fyuvayapan@gmail.com, https://orcid.org/0000-0002-7924-0933

Assoc. Prof. Dr., Osmaniye Korkut Ata University, Osmaniye, Turkey, ceyhunyukselir@gmail.com, https://orcid.org/0000-0003-4781-3183
}

Citation Information

Yuvayapan, F. \& Yükselir, C. (2020). A systematic review of corpus-based studies on academic writing in the Turkish context. Kuramsal Ë̆itimbilim Dergisi [Journal of Theoretical Educational Science], 13(4), 630-645. 
As our own experience as academicians amply indicate that academic writing requires a knowledge of the conventions of the disciplines for the organization of academic texts, communication with readers and mitigation of stance, which ultimately assist us to gain credibility as a member of our discipline. For Hyland (2009), academic writing (AW) is "the ways of thinking and using language which exists in the academy" (p. 1). He further explains that its significance lies in the fact that it creates academics based on particular social roles and relationships. Academic community exists with academic writing through which academicians construct knowledge either by competing or collaborating with other members of that community.

In recent decades, there has been a shift from faceless and impersonal academic discourse to a more personal discourse in which authors basically convince their readers rather than merely to present the findings of research. Lafuente-Milán (2010) explains the essence of this traditional view. Academic writing can be deemed as impersonal and objective because science is based on empirical results which are not associated with personal judgments or subjective ideas. Due to this change, academic discourse is coming to be viewed as a social discourse centred on credible and persuasive presentation of the content and claims.

Murray and Moore (2006) state that the development in our academic community as an academic writer depends on what we write. It is this realization which puts academic writing at the core of academic performance and success. It is a process of negotiating ideas in a socially-constructed academic text through expected conventions. Similarly, Burke (2010) contends that academic writing is a social process. In general, writers, researchers, academicians address to meaning together with severe arguments and finally reach a consensus with their readers. To achieve this, they use strategies objectively at the interpersonal level. Another way is to make rhetorical choices expected in a particular discipline.

Hyland (2009) explains the relationship between academic discourse and community sustained by academic persuasion. This social act is created by writers' attempts to convince their readers about the right choice of the content and their claims. To do this, they must make use of various linguistic devices that are bound to expectations and conventions of disciplinary communities. Simply put, disciplinary academic communities are responsible for yielding these conventions to their members. On one hand, the employment of these devices conveys cultural authority to guarantee the truth of knowledge. On the other hand, if we accept the fact that in the globallyoriented academic communities English is the medium, academicians not only follow the cultural conventions of their disciplines and publish in their own language but also publish in English for the participation of global academic communities of their discipline.

There are clearly differences among disciplines that are culturally and globally oriented and the key to exist in these different dimensions of disciplinary communities is to develop an understanding and awareness of linguistic devices of both dimensions and apply them appropriately in various kinds of academic genres. In the light of this information, the ultimate purpose of this review is to provide an evaluation of corpusbased academic writing studies conducted by Turkish scholars in the field of English Language Teaching and Linguistics. In doing so, we intend to present how Turkish writers of English foreground their stance by using various linguistic devices in 
different academic genres compared to native speakers of English. Revealing linguistics conventions of Turkish scholars in English may provide us with appropriate cues while writing academic genres in English. To our knowledge, no previous studies have been concerned with L2 cultural conventions of Turkish communities by concentrating on all major linguistic devices. The significance of this review lies in the fact that it reflects an overview of major linguistic devices used by Turkish-speaking academic writers. It is assumed that the results will be beneficial especially for postgraduate students and novice academic writers in the disciplines related to English language.

\section{Linguistic Devices in Academic Writing}

Because academic discourse is disciplinary and culturally mediated, academic writers need to follow the conventions of their disciplines to construct their stance, organize their texts and to negotiate with their readers. In the literature of academic discourse, linguistic features have received considerable attention. In this review, we will first examine a concept, authorial stance which is maintained through the use of various linguistic devices. Authorial stance in academic texts is considered to have a central role in gaining a credible place in these communities. For Biber (2006), stance refers to the expression of "many different kinds of personal feelings and assessments, including attitudes that a speaker has about certain information, how certain they are about its veracity, how they obtained access to information, and what perspective they are taking" (p. 99). In a way, stance-taking is a means of developing an identity rested on the conventions of the disciplinary community.

Stance-taking in academic writing can be maintained through a wide range of linguistic devices. Biber, Johanston, Leech, Conrad and Finegan (1999) explain different ways of expressing stance in the Longman Grammar of Spoken and Written English. Writers signal their stance through grammatical or lexical means and among them adverbials and complement clauses with verbs and adjectives are two common grammatical devices used to express stance. They also suggest a semantic distinction of stance markers including three categories: epistemic, attitudinal, style of speaking. Epistemic stance markers convey speaker's attitudes towards the propositional content while attitudinal markers indicate personal attitudes or feelings. Style of speaking is used to convey speaker's comments on the communication itself. A high number of previous studies have been published on these stance categories (Ağçam, 2015; Arrese, 2009; Biber, 2004; Charles, 2003; Dancygier \& Sweetser, 2000; Simon-Vanderbergen, 2008).

Metadiscourse (MD), which includes linguistic devices for the construction of stance in academic genres, has become an important research field since it was firstly defined by Zellig Harris in 1959. In its broad terms, it is described as "expressing the writer's acknowledgment of the reader" (Dahl, 2004, p. 1811). Adel (2006) defines it as "text about text. Metadiscourse is an element of the discourse about the evolving discourse, or the writers' explicit commentary on her own ongoing text” (p. 2). Broadly speaking, MD refers to organization of the interactions between writers and readers (Hyland, 2005). MD has been a question of interest with its disciplinary and cultural aspects (Abdi, 2009; Blagojevic, 2004; Burneikaite, 2008; Cao \& Hu, 2014; Hyland, 1998; Hyland, 2004; Hyland, 2010; Özdemir \& Longo, 2014). 
Another linguistic device employed in academic writing is called lexical bundles (LBs). Biber et al. (1999) define them as "recurrent expressions, regardless of their idiomaticity, and regardless of their structural status" (p. 990). They can consist of two or more words recurred frequently. They are also widely used by different speakers in different situations. Hyland (2008a) states that bundles pave the way for meaningmaking and creating distinctiveness in a register and participation in a community. In order to maintain a new language or a register, novices have to be aware of the expert's preferences of lexical bundles. This linguistic device has also received critical attention (Biber, Conrad \& Cortes, 2004; Cortes, 2004; Lu \& Deng, 2019; Karabacak \& Qin, 2012; Muşlu, 2018).

Overall, stance devices, MD and LBs are among the mostly used rhetorical devices that academicians employ to maintain various functions: organization of the text, stance-taking, negotiation with readers and most prominently becoming a member of the discipline. Clearly, they are all shaped by culturally and globally-oriented conventions of academic communities. Hence, it is a prerequisite for academic writers to be aware of them and use them appropriately to meet the expectations of particular academic communities in terms of these two layers.

\section{Method}

The data used in this study were comprised of four doctoral dissertations, one MA thesis, six research articles (RAs) related to stance-taking, five RAs concerning with MD and 4 RAs examined LBs (see Appendix A). All these studies were associated with cross-linguistic and cross-cultural issues of academic writing carried out between 2009 and 2019. The dissertations and thesis were downloaded from the database of Higher Educational Council and the research articles were compiled from different journals based on the linguistic features to be investigated.

In this systematic review, all studies were selected from cross-cultural corpusbased studies in the field of English Language Teaching and Linguistics. The main reason for this choice is that corpus linguistics paves the way to capture language use in real contexts. Since our aim is to figure out L2 cultural conventions of Turkish-speaking academic writers in these fields, we need to concentrate on the studies that present detailed analysis of linguistic devices. As stated by Meunier (2002), corpus-based studies have led the identification of patterned norms of English language with regards to grammatical and lexical patterns. Focusing on grammatical patterns in various text types in language can make grammatical description of different types of communication in various contexts clearer.

So as to supply a comprehensive review of the studies, we followed a systematic review process. Petticrew and Roberts (2006) state that systematic reviews are a means of comprehending large bodies of information by providing a step-by-step process of synthesizing studies to reach general conclusions. It can be applied:

- when there is uncertainty,

- when it is known there is a wide range of research on a subject but where key questions remain unanswered,

- when a general picture of the evidence in a topic area is needed to direct future research efforts (p. 21). 
The first step of this systematic review is to clarify the criteria for the selection of the studies to be reviewed:

- Only accessible studies that were written in English language were considered.

- Only cross-cultural corpus-based studies were selected since they will yield the real data necessary for this review.

- The most recent research about linguistic devices in academic writing was determined by putting check between the years 2009 and 2019 so that the last decade of research would appear.

- Since the use of linguistic devices varies across academic genres, we attempted to examine different types of them (doctoral dissertations, MA theses and research articles).

Secondly, we categorized the studies into three areas depending on the linguistic devices they examined: stance, metadiscourse and lexical bundles. Finally, the studies appropriate for this review were evaluated to provide a comprehensive overview of L2 cultural conventions employed in the disciplines related to English language by Turkish academic writers.

\section{Results and Discussion}

In this study, the studies taken into consideration, as stated before, are based on the linguistic devices; stance, metadiscourse and lexical bundles. The following sections show these linguistic devices respectively by giving information about the genre, corpus, aim and results of the studies. This first table of the present review is mainly concerned about stance-taking studies in English. All of them were published between 2009-2019 in Turkish context.

Table 1

Studies about Stance-Taking

\begin{tabular}{|c|c|c|c|c|}
\hline Author & Genre & Corpus & Aim & Results \\
\hline Ağçam, 2014 & $\mathrm{PhD}$ thesis & $\begin{array}{l}136 \mathrm{PhD} \text { theses written } \\
\text { by native and non-native } \\
\text { academic writers of } \\
\text { English }\end{array}$ & $\begin{array}{l}\text { To investigate the } \\
\text { epistemic stance } \\
\text { devices used for } \\
\text { stance-taking in } \\
\text { Academic } \\
\text { English. }\end{array}$ & $\begin{array}{l}\text { The overuse of certainty } \\
\text { devices in nonnative } \\
\text { corpora reflect that they } \\
\text { were confident in } \\
\text { presenting their claims. }\end{array}$ \\
\hline $\begin{array}{l}\text { Çandarlı, } \\
\text { Bayyurt and } \\
\text { Martı (2014) }\end{array}$ & RA & $\begin{array}{l}\text { Three corpora including } \\
\text { argumentative essays } \\
\text { (English essays by } \\
\text { Turkish students, Turkish } \\
\text { essays by Turkish } \\
\text { students and LOCNESS) }\end{array}$ & $\begin{array}{l}\text { To compare } \\
\text { Stance features in } \\
\text { L1 and L2 } \\
\text { corpora by } \\
\text { Turkish learners } \\
\text { of English }\end{array}$ & $\begin{array}{l}\text { Based on the findings, it } \\
\text { seems more authorial } \\
\text { presence markers in the } \\
\text { Turkish essays than the } \\
\text { English essays by either } \\
\text { the Turkish and } \\
\text { American students. }\end{array}$ \\
\hline Çakır (2016) & RA & $\begin{array}{l}240 \text { abstracts from the } \\
\text { disciplines of six } \\
\text { disciplines written by } \\
\text { Turkish and native } \\
\text { writers of English }\end{array}$ & $\begin{array}{l}\text { To explore how } \\
\text { academic writers } \\
\text { from different } \\
\text { disciplines put } \\
\text { author stance in }\end{array}$ & $\begin{array}{l}\text { This study reveals that } \\
\text { native writers of English } \\
\text { used stance adverbs } \\
\text { highly compared to the } \\
\text { Turkish writers of }\end{array}$ \\
\hline
\end{tabular}




\begin{tabular}{|c|c|c|c|c|}
\hline & & & $\begin{array}{l}\text { the abstracts of } \\
\text { research articles }\end{array}$ & English. \\
\hline $\begin{array}{l}\text { Işık-Taş } \\
(2018)\end{array}$ & RA & $\begin{array}{l}130 \text { research articles in } \\
\text { Turkish and in English in } \\
\text { Sociology }\end{array}$ & $\begin{array}{l}\text { To figure out how } \\
\text { authorial identity } \\
\text { is shown through } \\
\text { first person } \\
\text { pronouns }\end{array}$ & $\begin{array}{l}\text { The findings revealed } \\
\text { extensive similarities in } \\
\text { the frequency and } \\
\text { discourse functions of } \\
\text { first person pronouns in } \\
\text { English RAs written by } \\
\text { native and Turkish } \\
\text { researchers. }\end{array}$ \\
\hline Kafes (2018) & $\mathrm{RA}$ & $\begin{array}{l}45 \text { research articles } \\
\text { published in Social } \\
\text { Behavior and Personality } \\
\text { between } 1993 \text { and } 2007\end{array}$ & $\begin{array}{l}\text { To investigate } \\
\text { author stance in } \\
\text { research articles }\end{array}$ & $\begin{array}{l}\text { American academic } \\
\text { writers employed more } \\
\text { stance devices than } \\
\text { Spanish and Turkish } \\
\text { academic writers of } \\
\text { English }\end{array}$ \\
\hline $\begin{array}{l}\text { Karahan } \\
(2013)\end{array}$ & RA & $\begin{array}{l}40 \text { research articles } \\
\text { written by Turkish and } \\
\text { non-Turkish authors }\end{array}$ & $\begin{array}{l}\text { To find out the } \\
\text { distribution of "I" } \\
\text { and "we" } \\
\text { pronouns }\end{array}$ & $\begin{array}{l}\text { Turkish writers used less } \\
\text { "I" and "we" pronouns } \\
\text { than non-Turkish writers. }\end{array}$ \\
\hline $\begin{array}{l}\text { Yuvayapan } \\
(2018 b)\end{array}$ & $\mathrm{RA}$ & $\begin{array}{l}\text { Doctoral dissertations by } \\
\text { American academic } \\
\text { writers, Turkish } \\
\text { academic writers of } \\
\text { English who earned their } \\
\text { PhD at Turkish } \\
\text { universities and Turkish } \\
\text { academic writers of } \\
\text { English who did their } \\
\text { PhD in the USA. }\end{array}$ & $\begin{array}{l}\text { To examine the } \\
\text { self-mentions } \\
\text { distribution }\end{array}$ & $\begin{array}{l}\text { Turkish writers used less } \\
\text { self-mentions than } \\
\text { American academic } \\
\text { writers However, } \\
\text { Turkish writers who did } \\
\text { their doctoral studies in } \\
\text { the USA used more self- } \\
\text { mentions than Turkish } \\
\text { writers who completed } \\
\text { their doctoral studies in } \\
\text { Turkey. }\end{array}$ \\
\hline
\end{tabular}

Table 1 summarizes some studies comparing stance-taking conventions of native and Turkish-speaking academic writers of English. Focusing on epistemic stance devices, Ağçam (2014) found out that epistemic stance devices were employed more frequently by native academic writers when compared to Spanish and Turkish academic writers. It is likely that non-native academic writers adopted L1 conventions in their L2 dissertations and mitigated a more confident stance while presenting their claims whereas native academic writers stamped a more cautious style. Çandarlı, Bayyurt and Mart1 (2014) examined the linguistic devices of stance in L1 and L2 essays written by Turkish-speaking students of English and concluded that they tended to utilize more authorial presence markers in their Turkish essays compared to their English essays written by Turkish students and those by American students, which might indicate that they tried to adopt English linguistic conventions in their L2 essays. In another study, Çakır (2016) pointed out that the abstracts of research articles by native writers of English included more stance adverbs than those by Turkish writers. This attempt showed that native writers aimed to emphasize the truth of propositional content. Kafes (2018) specifically focused on the use of modal verbs to stamp stance in research articles and found out that Spanish and Turkish academic writers of English tended to 
employ less stance devices than American academic writers. He reported that Turkish and Spanish academic writers in that study developed a style of combining the global and cultural linguistic conventions of their disciplines. Yuvayapan (2018b) also investigated the distribution of self-mentions and concluded that American academic writers build a more explicit stance with the use of more self-mentions unlike Turkish academic writers. Another researcher, Işık-Taş (2017) explored how authorial stance is constructed with first-person pronouns and observed striking similarities in the use of first-person pronouns in English research articles by native and Turkish academics. Karahan (2013) also investigated "I" and "We" pronouns and reported that Turkish had a tendency of using less first-person pronouns than non-Turkish writers.

Taken together, these studies show that the linguistic mechanism used by academic writers of English to stamp their stance vary depending on the disciplines, cultures and genres. As Hyland (2004) puts, disciplinary communities have an influence on rhetorical practices of arguing the claims and engaging readers into texts. Seemingly, they indicate the rarity of stance expressions in the genres written by Turkish academic writers of English when compared to native academic writers of English. For instance, the less use of first-person pronouns in this community clearly prove that they avoid taking an explicit stance. In addition, Turkish academic writers express their stance differently in L1 and L2 academic genres. They tend to hold the conventions of native academic writers while writing in English. It seems that they feel obliged to follow the conventions of their cultural academic community as well as to adhere the global conventions of their discipline to be credible in L2 academic discipline. However, the mixture of linguistic devices of two culture may lead to problems in stance-taking and getting credibility in the global academic community.

Table 2

Studies about Metadiscourse

\begin{tabular}{|c|c|c|c|c|}
\hline Author & Genre & Corpus & Aim & Results \\
\hline Çapar, 2014 & $\mathrm{PhD}$ thesis & $\begin{array}{l}150 \text { research articles } \\
\text { (50 English research } \\
\text { articles written by } \\
\text { American academic } \\
\text { writers (AAWs), } \\
\text { Turkish academic } \\
\text { writers (TAWs) and } \\
50 \text { Turkish } \\
\text { research articles } \\
\text { written by TAWs }\end{array}$ & $\begin{array}{l}\text { To examine the use } \\
\text { of interactional } \\
\text { metadiscourse } \\
\text { markers (IMM) in } \\
\text { research articles }\end{array}$ & $\begin{array}{l}\text { Based on the results, } \\
\text { AAWs used } \\
\text { significantly more } \\
\text { IMMs in English } \\
\text { research articles } \\
\text { compared to IMMs } \\
\text { in English and } \\
\text { Turkish research } \\
\text { articles written by } \\
\text { TAWs. }\end{array}$ \\
\hline $\begin{array}{l}\text { Yuvayapan, } \\
(2018 \mathrm{a})\end{array}$ & $\mathrm{PhD}$ thesis & $\begin{array}{l}120 \text { doctoral } \\
\text { dissertations written } \\
\text { between } 2010 \text { and } \\
2015\end{array}$ & $\begin{array}{l}\text { To compare the use } \\
\text { of interactional } \\
\text { metadiscourse } \\
\text { markers (IMDMs) by } \\
\text { native academic } \\
\text { authors of English } \\
\text { (NAAEs) and } \\
\text { Turkish-speaking } \\
\text { academic authors of }\end{array}$ & $\begin{array}{l}\text { The results show that } \\
\text { Turkish-speaking } \\
\text { academic authors of } \\
\text { English underused } \\
\text { IMDMs regarding } \\
\text { the overall use of } 5 \\
\text { subcategories of } \\
\text { IMDMs. }\end{array}$ \\
\hline
\end{tabular}




\begin{tabular}{|c|c|c|c|c|}
\hline $\operatorname{Alg}_{1}(2012)$ & MA thesis & $\begin{array}{l}104 \text { (52 Turkish and } \\
52 \text { English) } \\
\text { argumentative } \\
\text { paragraphs }\end{array}$ & $\begin{array}{l}\text { To investigate the } \\
\text { types, frequencies } \\
\text { and functions of } \\
\text { hedges and boosters } \\
\text { in L1 and L2 } \\
\text { argumentative } \\
\text { paragraphs }\end{array}$ & $\begin{array}{l}\text { This study concludes } \\
\text { that the number of } \\
\text { hedges and boosters } \\
\text { in L2 paragraphs } \\
\text { were not much } \\
\text { higher than that of } \\
\text { L1 }\end{array}$ \\
\hline Akbaş (2012) & RA & $\begin{array}{l}90 \text { abstracts of } \\
\text { dissertations in the } \\
\text { Social Sciences }\end{array}$ & $\begin{array}{l}\text { To explore } \\
\text { metadiscourse in the } \\
\text { dissertation abstracts } \\
\text { written by Native } \\
\text { Speakers of Turkish } \\
\text { (NST), } \\
\text { Turkish Speakers of } \\
\text { English (TSE) and } \\
\text { Native Speakers of } \\
\text { English (NSE) in the } \\
\text { Social Sciences }\end{array}$ & $\begin{array}{l}\text { The results of the } \\
\text { study show that } \\
\text { English-speaking } \\
\text { writers wrote their } \\
\text { abstracts } \\
\text { with more interaction } \\
\text { and guidance unlike } \\
\text { Turkish writers. }\end{array}$ \\
\hline Akbaş (2014) & RA & $\begin{array}{l}20 \text { discussion } \\
\text { sections from MA } \\
\text { dissertations written } \\
\text { by Turkish writers in } \\
\text { L1 and L2 }\end{array}$ & $\begin{array}{l}\text { To figure out how } \\
\text { interactional } \\
\text { metadiscourse is used } \\
\text { by Turkish writers in } \\
\text { Turkish and English } \\
\text { in this section }\end{array}$ & $\begin{array}{l}\text { The results reveal } \\
\text { that there were some } \\
\text { similarities and } \\
\text { statistically } \\
\text { significant } \\
\text { differences between } \\
\text { the two corpora } \\
\text { regarding } \\
\text { interactional } \\
\text { metadiscourse }\end{array}$ \\
\hline Ekoç (2010) & RA & $\begin{array}{l}40 \text { MA theses } \\
\text { abstracts }\end{array}$ & $\begin{array}{l}\text { To reveal Turkish } \\
\text { MA students' use of } \\
\text { lexical hedging } \\
\text { strategies in MA } \\
\text { theses abstracts from } \\
\text { different fields }\end{array}$ & $\begin{array}{l}\text { The study concludes } \\
\text { that MA students use } \\
\text { different hedging } \\
\text { strategies }\end{array}$ \\
\hline Yuvayapan (2019) & RA & $\begin{array}{l}60 \text { doctoral } \\
\text { dissertations }\end{array}$ & $\begin{array}{l}\text { To examine the use } \\
\text { of metadiscursive } \\
\text { nouns written by } \\
\text { American academic } \\
\text { writers of English } \\
\text { and Turkish-speaking } \\
\text { academics of English }\end{array}$ & $\begin{array}{l}\text { As for the results, } \\
\text { both groups of } \\
\text { academic writers in } \\
\text { the study showed } \\
\text { similarities on the } \\
\text { total preference of } \\
\text { metadiscoursive } \\
\text { nouns }\end{array}$ \\
\hline $\begin{array}{l}\text { Özdemir and } \\
\text { Longo (2014) }\end{array}$ & RA & 52 thesis abstracts & $\begin{array}{l}\text { To investigate } \\
\text { cultural variations in } \\
\text { the use of } \\
\text { metadiscourse } \\
\text { between Turkish and } \\
\text { USA postgraduate } \\
\text { students' abstracts in } \\
\text { English MA thesis }\end{array}$ & $\begin{array}{l}\text { The results show that } \\
\text { there were some } \\
\text { cultural differences } \\
\text { in metadiscourse } \\
\text { amounts and types }\end{array}$ \\
\hline
\end{tabular}

English (TAAEs)

To investigate the hedges and boosters in L1 and L2 argumentative

To explore

metadiscourse in the dissertation abstracts written by Native Speakers of Turkish (NST), English (TSE) and English (NSE) in the ciences Turkish and English in this section

o reveal Turkish lexical hedging theses abstracts from

To examine the use writers of English and Turkish-speaking 
Regarding metadiscourse, one of the most frequently applied linguistic device of stance-taking, this review included eight studies. Out of eight, five are research articles, two PhD studies and just one MA study. In a corpus including research articles, Çapar (2014) examined the use of interactional metadiscourse markers (IMMs) and observed that American academic writers made use of more IMMs than Turkish academic writers in their L1 and L2 research articles. Yuvayapan (2018a) compared the use of interactional metadiscourse markers by native academic writers of English and Turkishspeaking academic writers of English. In this doctoral dissertation, the writer found out that these devices were statistically underused by Turkish academic writers. Alg1 (2012) investigated how hedges and boosters were employed in L1 and L2 argumentative paragraphs written by Turkish learners of English and concluded that these devices were more frequented in L2 paragraphs than that of L1 paragraphs. Akbaş (2012) conducted a study to figure out MD in dissertation abstracts written by native and Turkish speakers of English in Social Sciences and revealed that Turkish speakers of English mitigated their stance by using a mixture of global and cultural norms of their L1 and L2. In a similar vein, Akbaş (2014) also investigated the interactional metadiscourse in the discussion section of dissertations and observed that Turkish academic writers signalled a more objective stance in their L1 while they maintained a more personal stance with the use of self-mentions in English. Ekoç (2010) tried to identify hedging strategies in MA abstracts produced by Turkish academic writers and found disciplinary variations. Yuvayapan (2019) examined the use of MD nouns written by American academic writers of English and Turkish writers of English and reported similarities on the overall use of MD nouns. On the contrary, Özdemir and Longo (2014) observed cultural differences in the distribution of MD.

The cultural and disciplinary differences become more apparent with the review of studies concerned with MD. In accordance with Mur-Duenas's study (2011) conducted in Spanish context, this particular linguistic device is predominantly a convention of native academic community and virtually it is the means of engagement, construction of stance and organization of texts. The relative underuse of it by Turkish academic writers of English may underline a preference of impersonality and less interaction with readers since such investment do not carry a certain risk about the truth of the propositional content in the lens of readers. On the contrary, native academic writers of English feel comfortable in explicitly aligning themselves in their academic texts and directing their readers to ensure the accurate understanding of the content with the frequent use of MD.

Table 3

Studies about Lexical Bundles

\begin{tabular}{lllll}
\hline Author & Genre & Corpus & Aim & Results \\
\hline Güngör (2016) & PhD Thesis & $\begin{array}{l}\text { 250 research articles } \\
\text { in the discipline of } \\
\text { educational sciences }\end{array}$ & $\begin{array}{l}\text { To explore four- } \\
\text { word lexical } \\
\text { bundles in L2 } \\
\text { English and L1 } \\
\end{array}$ & $\begin{array}{l}\text { Turkish } \\
\text { results, on account } \\
\text { of cross-linguistic } \\
\text { influence, there } \\
\text { was different } \\
\text { employment of } \\
\text { lexical bundles in }\end{array}$
\end{tabular}




\begin{tabular}{|c|c|c|c|c|}
\hline & & & & $\begin{array}{l}\text { L2 English and L1 } \\
\text { Turkish }\end{array}$ \\
\hline $\begin{array}{l}\text { Güngör and Uysal } \\
\text { (2016) }\end{array}$ & $\mathrm{RA}$ & $\begin{array}{l}\text { Research } \\
\text { articles in the } \\
\text { discipline of } \\
\text { educational sciences }\end{array}$ & $\begin{array}{l}\text { To compare the } \\
\text { structural and } \\
\text { functional } \\
\text { characteristics of the } \\
\text { lexical-bundle use } \\
\text { in L1 and L2 } \\
\text { research articles } \\
\text { written in English }\end{array}$ & $\begin{array}{l}\text { The results reveal } \\
\text { that } \\
\text { the deviation of the } \\
\text { usages of lexical } \\
\text { bundles by the } \\
\text { non-native } \\
\text { speakers of } \\
\text { English }\end{array}$ \\
\hline $\begin{array}{l}\text { Güngör and Uysal } \\
(2020)\end{array}$ & RA & $\begin{array}{l}\text { A three-million } \\
\text { word based on } \\
\text { research article } \\
\text { corpus, each of } \\
\text { which contains one } \\
\text { million words in L1 } \\
\text { English, L2 English } \\
\text { and L1 Turkish } \\
\text { articles in the field } \\
\text { of educational } \\
\text { sciences }\end{array}$ & $\begin{array}{l}\text { To find out any } \\
\text { crosslinguistic } \\
\text { influence of L1 } \\
\text { Turkish and L2 } \\
\text { English }\end{array}$ & $\begin{array}{l}\text { The results show } \\
\text { that there is the } \\
\text { transfer of } 54 \\
\text { bundles from L1 } \\
\text { Turkish to their L2 } \\
\text { English }\end{array}$ \\
\hline $\begin{array}{l}\text { Karabacak and } \\
\text { Qin (2013) }\end{array}$ & RA & $\begin{array}{l}\text { Argumentative } \\
\text { papers written by } \\
\text { three groups of } \\
\text { university writers, } \\
\text { Turkish, Chinese, } \\
\text { and Americans } \\
\text { a reference corpus, } \\
\text { New York Times } \\
\text { articles }\end{array}$ & $\begin{array}{l}\text { To investigate the } \\
\text { use of lexical } \\
\text { bundles in } \\
\text { argumentative } \\
\text { papers by three } \\
\text { groups of university } \\
\text { writers: Turkish, } \\
\text { Chinese and } \\
\text { Americans. }\end{array}$ & $\begin{array}{l}\text { The results of the } \\
\text { study show that } \\
\text { American students } \\
\text { applied to five- } \\
\text { word bundles more } \\
\text { frequently than } \\
\text { both Turkish and } \\
\text { Chinese students } \\
\text { Bundles used by } \\
\text { Turkish and } \\
\text { Chinese students } \\
\text { were not employed } \\
\text { by American } \\
\text { students }\end{array}$ \\
\hline Muşlu (2018) & RA & $\begin{array}{l}\text { Louvain Corpus of } \\
\text { Native English } \\
\text { Essays (LOCNESS), } \\
\text { Japanese } \\
\text { International Corpus } \\
\text { of Learner English } \\
\text { (JPICLE) and } \\
\text { Turkish } \\
\text { International Corpus } \\
\text { of Learner English } \\
\text { (TICLE) }\end{array}$ & $\begin{array}{l}\text { To find out the most } \\
\text { common stance LBs } \\
\text { used in } \\
\text { argumentative } \\
\text { essays written by } \\
\text { native English } \\
\text { speakers and } \\
\text { Turkish and } \\
\text { Japanese EFL } \\
\text { learners. }\end{array}$ & $\begin{array}{l}\text { Native speakers } \\
\text { use lexical bundles } \\
\text { least; whereas, } \\
\text { Japanese EFL } \\
\text { learners use them } \\
\text { most frequently. }\end{array}$ \\
\hline
\end{tabular}

Table 3 shows the studies about lexical bundles. There are four studies and one of them is doctoral dissertation in the Turkish context. Güngör (2016) examined four-word LBs in L2 English and L1 Turkish in doctoral dissertation and concluded that there were different employments of LBs due to cross-linguistic difference. Güngör and Uysal 
(2016) also carried out a comparative study and revealed different use of LBs by nonnative speakers of English from native speakers. In argumentative essays, Karabacak and Qin (2013) investigated the use of LBs and claimed that American students applied five-word bundles more frequently than both Turkish and Chinese students. Pointing to finding out the most common LBs in argumentative essays, Muşlu (2018) calculated that LBs were more frequented in essays by Japanese EFL learners than those of Turkish and American.

LBs are another linguistic device that enhance communicative competence in academic writing. They seem to be highly influential in organizing the texts, persuading readers and mitigating stance in academic writing. The use of these formulaic patterns seems to vary enormously based on disciplines and cultures. The studies above suggest that there is a heavy reliance of LBs by Turkish academic writers while writing in English compared to native academic writers of English, which may be tied to inefficiency in English and the lack of the control of academic writing norms in L2 (Hyland, 2008b). It is also probable that they may transfer some bundles applied in their L1 Turkish to L2 context, as claimed by Güngör and Uysal (2020). Overall, this systematic review enabled us to suggest that academic writers stamp their self in their academic texts through different linguistic devices based on cultural and disciplinary norms, as emphasized by Dahl (2004).

\section{Conclusion}

In this review study, corpus-based studies on linguistic devices of academic writing conducted by Turkish scholars in the field of English Language Teaching and Linguistics in the last decade have been reviewed and implications for future research and practice have been suggested. The studies included in the study were selected in accordance with systematic review such as accessible studies, cross-cultural corpusbased studies and linguistic devices (stance, metadiscourse and lexical bundles). Taking these studies into consideration, the studies were evaluated in order to give a comprehensive view and insight of L2 cultural conventions of Turkish academic writers. Based on the studies reviewed, it can be said that academic genres are characterized by different linguistic devices depending on cultures and disciplines. The appropriate use of them is the reflection of academic writers' disciplinary competence both in their cultural and global community. A kind of impersonal and implicit academic negotiation is created by Turkish academic writers of English by the less frequent use of stance and MD features. The abundant employment of lexical bundles may indicate that Turkish academic writers may be less confident in shaping their texts, positioning themselves and their readers while writing in English, which is not parallel to the rhetorical conventions of native academic community.

After all, this review is an attempt to provide an overview of cross-cultural corpus-based studies on academic writing. In relation to this, some of the pedagogical implications can be given. First, Turkish writers of English seem to hold impersonal attitude in their L1 and L2 compared to native speakers. This situation can lead to lessen the academic quality of the studies published in English-medium global context. So, the writers have to put emphasis on undertaking an explicit stance with the use of global rhetorical conventions while writing their paper in L2. Second, the underuse of metadiscourse linguistic device create less interactive atmosphere with the readers, thus 
the writers do not communicate with their readers persuasively, which increases the risk of being rejected by their readers. Regarding this, Turkish writers of English should explicitly align themselves in the studies through frequent use of metadiscourse devices. Last but not least, the awareness of common global lexical bundles in their disciplines is essential for Turkish academic writers of English. The abundant use of them may not indicate a native-like employment, as can be concluded from our review.

As stated before, the ultimate aim of academic writing courses should be to help academic students to develop academic identity with the conscious and appropriate use of linguistic devices of their disciplines both in global and cultural academic discourse. In the implementation of courses, the following points need to be taken into consideration.

- It is essential for EAP teachers to highlight dissimilar ways in different disciplinary environments (Pang, 2010). The most effective way of doing this is using corpus-informed lists and concordances as a teaching material to identify the linguistic norms of their disciplines (Hyland, 2008b).

- It is also beneficial to concentrate on genre-based and disciplinary-specific norms of academic writing to develop academic students' awareness of the cultural and universal norms of academic genres in their disciplines should be developed.

- Consciousness-raising method suggested by Hyland (2005) would create academic writers who are aware of the linguistic conventions their disciplines. This approach includes four steps: a- analysing the text to get familiar with the linguistic features; b- while manipulating texts students change sample texts; $c$ - implementing some activities to understand the audience is also necessary to raise audience awareness; d- in the last step, students create their own academic texts.

The present study is an attempt to reveal L2 linguistic conventions of Turkish academic community through the synthesis of the current studies conducted in the last decade. Further studies should focus on the changes in the linguistic conventions in Turkish academic community from a historical perspective. To illustrate, the present study is limited to the last decade. A systematic review study emphasizing the conventions in the last five decades can shed a light on how these conventions have changed historically.

\section{Statement of Responsibility}

Fatma Yuvayapan; conceptualization, methodology, validation, formal analysis, investigation, resources, data curation, writing - original draft, writing - review \& editing, visualization, supervision, project administration. Ceyhun Yükselir; conceptualization, methodology, validation, writing - original draft, writing - review \& editing, visualization, supervision, project administration. 


\section{References}

Abdi, R. (2009). Projecting cultural identity through metadiscourse marking: A comparison of Persian and English research articles. Journal of English Language Teaching and Learning, 1(212), 1-15.

Adel, A. (2006). Metadiscourse in L1 and L2 English. Amsterdam: John Benjamin Publishing Company.

Ağçam, R. (2015). A corpus-based study on attitudinal stance in native and non-native academic writing. International Journal of Humanities Social Sciences and Education (IJHSSE), 2(8), 123-129.

Arrese, J. I. M. (2009). Effective vs. epistemic stance, and subjectivity/intersubjectivity in political discourse. A case study. Studies on English modality in honour of Frank Palmer. Linguistic Insights, 111, 23-131.

Blagojevic, S. (2004). Metadiscourse in academic prose: A contrastive study of academic articles written in English by English and Norwegian native speakers. Studies about Linguistics, 5, 1-7.

Burke, S. B. (2010). The construction of writer identity in the academic writing of Korean ESL students: A qualitative study of six Korean students in the U.S. (Unpublished doctoral dissertation). Indiana University of Pennsylvania, Indiana.

Burneikaite, N. (2008). Metadiscourse in linguistics master's theses in English L1 and L2. Kalbotyra, 59(3), 38-48.

Biber, D., Johanston, S., Leech, G., Conrad, S., \& Finegan, E. (1999). Longman grammar of spoken and written English. Edinburg: Pearson Education.Burke

Biber, D. (2004). Historical patterns for the grammatical marking of stance: A crossregister comparison. Journal of Historical Pragmatics, 5(1), 107-136.

Biber, D., Conrad, S., \& Cortes, V. (2004). If you look at...: Lexical bundles in university teaching and textbooks. Applied Linguistics, 25(3), 371-405.

Biber, C. (2006). Stance in spoken and written university registers. Journal of English for Academic Purposes, 5, 97-116.

Cao, F., \& Hu, G. (2014). Interactive metadiscourse in research articles: A comparative study of paradigmatic and disciplinary influences. Journal of Pragmatics, 66(2014), 15-31.

Charles, M. (2003). 'This mystery...': a corpus-based study of the use of nouns to construct stance in theses from two contrasting disciplines. Journal of English for Academic Purposes, 2(4), 313-326.

Cortes, V. (2004). Lexical bundles in published and student disciplinary writing: Examples from history and biology. English for Specific Purposes, 23(4), 397423.

Dahl, T. (2004). Textual metadiscourse in research articles: A marker of national culture or of academic discipline. Journal of Pragmatics, 36, 1807-1825.

Dancygier, B., \& Sweetser, E. (2000). Constructions with if, since, and because: Causality, epistemic stance, and clause order. Topics in English Linguistics, 33, 111-142. 
Güngör, F. \& Uysal, H. (2020). Lexical bundle use and cross-linguistic influence in academic texts. Lingua, 242, 1-21.

Hyland, K. (1998). Persuasion and context: The pragmatics of academic metadiscourse. Journal of Pragmatics, 30, 437-455.

Hyland, K. (2004). Disciplinary interactions: Metadiscourse in L2 postgraduate writing. Journal of Second Language Writing, 13, 133-151.

Hyland, K. (2005). Metadiscourse: Exploring interaction in writing. London: Continuum.

Hyland, K. (2008a). As can be seen: Lexical bundles and disciplinary variation. English for Specific Purposes, 27, 4-21.

Hyland, K. (2008b). Academic clusters: Text patterning in published and postgraduate writing. International Journal of Applied Linguistics, 18(1), 41-62.

Hyland, K. (2009). Academic discourse. London: Cambridge University Press.

Hyland, K. (2010). Metadiscourse: Mapping interactions in academic writing". Nordic Journal of English Studies, 9(2), 125-143.

Karabacak, E., \& Qin, J. (2013). Comparison of lexical bundles used by Turkish, Chinese, and American university students. Procedia-Social and Behavioral Sciences, 70, 622-628.

Lafuente-Milan, E.L. (2010). 'Extending this claim, we propose...' The writer's presence in research articles from different disciplines. Iberica, 20, 35-56.

Lu, X., \& Deng, J. (2019). With the rapid development: A contrastive analysis of lexical bundles in dissertation abstracts by Chinese and L1 English doctoral students. Journal of English for Academic Purposes, 39, 21-36.

Meunier, F. (2002). The pedagogical value of native learner corpora in EFL grammar teaching. In S. Granger, J. Hung \& S. Petch-Tyson (Eds.), Computer learner corpora, second language acquisition and foreign language teaching (pp. 119142). Amsterdam: John Benjamin Publishing.

Murray, M., \& Moore, S. (2006). The handbook of academic writing. Berkshire, England: Open University Press.

Muşlu, M. (2018). Use of stance lexical bundles by Turkish and Japanese EFL learners and native English speakers in academic writing. Gaziantep University Journal of Social Sciences, 17(4), 1319-1337.

Özdemir, N. Ö., \& Longo, B. (2014). Metadiscourse use in thesis abstracts: A crosscultural study. Procedia-Social and Behavioral Sciences, 141(2014), 59-63. https://doi.org/10.1016/j.sbspro.2014.05.011

Pang, W. (2010). Lexical bundles and the construction of an academic voice: A pedagogical perspective. Asian EFL Journal, 47(1), 10-11.

Petticrew, M., \& Roberts, H (2006). Systematic reviews in the social sciences: $A$ practical guide. Oxford, UK: Blackwell Publishing.

Simon-Vandenbergen, A. M. (2008). Almost certainly and most definitely: Degree modifiers and epistemic stance. Journal of Pragmatics, 40(9), 1521-1542.

Yuvayapan, F. (2018b). Stance-taking and self-mentions: The influence of academic community. International Journal of Language Academy. 6(3), 263-276. 


\section{Appendix A: Studies included in the review}

Ağçam, R. (2014). A Corpus-based Study on Author Stance in Academic English (Unpublished doctoral thesis). Çukurova University/Sosyal Bilimler Enstitüsü, Adana.

Akbaş, E. (2012). Interactional Metadiscourse in Turkish Postgraduates' Academic Texts: A Comparative Study of How They Introduce and Conclude. Journal on English Language Teaching, 2(3), 35-44.

Akbaş, E. (2014). Are they discussing in the same way? Interactional metadiscourse in Turkish writers' texts. In Occupying niches: Interculturality, cross-culturality and aculturality in academic research (pp. 119-133). Springer, Cham.

Alg1, S. (2012). Hedges and Boosters in L1 and L2 Argumentative Paragraphs: Implications for Teaching L2 Academic Writing. (Unpublished master's thesis). Middle East Technical University/Sosyal Bilimler Enstitüsü, Ankara.

Çakır, H. (2016). Native and non-native writers' use of stance adverbs in English research article abstracts. Open Journal of Modern Linguistics, 6(02), 85.

Çandarl1, D., Bayyurt, Y., \& Martı, L. (2015). Authorial presence in L1 and L2 novice academic writing: Cross-linguistic and cross-cultural perspectives. Journal of English for Academic Purposes, 20, 192-202.

Çapar, M. (2014). A Study on Interactional Metadiscourse Markers in Research Articles. (Unpublished doctoral thesis). Anadolu University/Eğitim Bilimleri Enstitüsü, Eskişehir.

Ekoç, A. (2010). Analyzing Turkish MA students' use of lexical hedging strategies in theses abstracts. HAYEF Journal of Education, 7(1), 49-62.

Güngör, F. (2016). Crosslinguistic Analysis of Lexical Bundles in L1 English, L2 English, and L1 Turkish Research. (Unpublished doctoral thesis). Gazi University/Eğitim Bilimleri Enstitüsü, Ankara.

Güngör, F., \& Uysal, H. H. (2016). A comparative analysis of lexical bundles used by native and non-native Scholars. English Language Teaching, 9(6), 176-188.

Güngör, F. \& Uysal, H. (2020). Lexical bundle use and cross-linguistic influence in academic texts. Lingua, 242, 1-21.

Iş1k-Taş, E. E. (2018). Authorial identity in Turkish language and English language research articles in Sociology: The role of publication context in academic writers' discourse choices. English for Specific Purposes, 49, 26-38.

Kafes, H. (2018). Stance in academic writing. European Journal of Education Studies. $4(2), 1-16$.

Karabacak, E., \& Qin, J. (2013). Comparison of lexical bundles used by Turkish, Chinese, and American university students. Procedia-Social and Behavioral Sciences, 70, 622-628. https://doi.org/10.1016/j.sbspro.2013.01.101

Karahan, P. (2013). Self-mention in scientific articles written by Turkish and nonTurkish authors. Procedia-Social and Behavioral Sciences, 70, 305-322. https://doi.org/10.1016/j.sbspro.2013.01.068 
Mur-Dueñas, P. (2011). An intercultural analysis of metadiscourse features in research articles written in English and in Spanish. Journal of pragmatics, 43(12), 30683079 .

Muşlu, M. (2018). Use of stance lexical bundles by Turkish and Japanese EFL learners and native English speakers in academic writing. Gaziantep University Journal of Social Sciences, 17(4).

Özdemir, N. O., \& Longo, B. (2014). Metadiscourse use in thesis abstracts: A crosscultural study. Procedia-Social and Behavioral Sciences, 141, 59-63.

Yuvayapan, F. (2018a). The Pragmatic Role of Interactional Markers in the Construal of Author Stance: A Cross-linguistic Study of PhD Dissertations. (Unpublished doctoral thesis). Erciyes University/Sosyal Bilimler Enstitüsü, Kayseri.

Yuvayapan, F. (2019). Metadiscursive nouns in doctoral dissertations: A comparison of native and nonnative speakers of English. Eğitimde Kuram ve Uygulama, 15(1), 7487. 